\title{
STEM-integrated encyclopaedia as the enrichment for elementary school students
}

\author{
Vera Yuli Erviana ${ }^{1}$ *, Anjar Purba Asmara ${ }^{2}$ \\ ${ }^{1}$ Department of Elementary School Education, Universitas Ahmad Dahlan. \\ Jalan Ki Ageng Pemanahan No. 19, Yogyakarta, 55162, Indonesia \\ ${ }^{2}$ University of Technology Sydney. 15 Broadway, Ultimo NSW 2007, Australia \\ * Corresponding Author. E-mail: vera.erviana@pgsd.uad.ac.id \\ Received: 9 August 2019; Revised: 17 September 2019; Accepted: 23 October 2019
}

\begin{abstract}
The objective of the study is to describe the effectiveness and the fitness of the STEM-Integrated encyclopaedia as the enrichment for the learning materials of Temperature and Heat among Grade $\mathrm{V}$ Students in the elementary school degree. Concerning the objective of the study, the nature of the study is Research and Development (R\&D). In conducting the R\&D, the ADDIE (Analysis, Design, Development, Implementation and Evaluation) model had been adopted. In overall, the Analysis was directed toward the problems that had occurred among the students, the Design was related to the media that should be presented to the students, the Development referred to the model of the media that had been in accordance to the needs of the students, the Implemented was related to the Development that had been performed and the Evaluation was directed toward the media that had been developed. In gathering the data, several techniques had been applied namely interview, test administration and questionnaire distribution. Then, in analysing the data both of the qualitative and the quantitative approach had been adopted. Furthermore, in testing the hypothesis, the paired t-test had been administrated to identify the results of the effectiveness of the study. Based on the results of the assessment by the media validator, the material validator and the learning validator, it might be concluded that the STEM-integrated encyclopaedia has been fit for the implementation of the learning process among the Grade V students within the elementary school degree. In the same time, the results of the test show that the effectiveness of the STEM-integrated encyclopaedia has been significant since in the conduct of the hypothesis test (t-test) using the paired t-test it is found that the t-count (10.325) > the t-table (2.048). Besides, it is also found that the significance (p-value) has been 0.000 , which is lower than the $\alpha 5.00 \%(0.0000<0.050)$ from the results of the comparison between the pre-test and the posttest. Therefore, the use of the STEM-integrated encyclopaedia has been fit for implementation in the elementary school degree.
\end{abstract}

Keyword: encyclopaedia, STEM-integrated, enrichment on materials of Temperature and Heat, elementary school

How to Cite: Erviana, V., \& Asmara, A. (2019). STEM-integrated encyclopaedia as the enrichment for elementary school students. Jurnal Prima Edukasia, 7(2), 114-127. doi:https://doi.org/10.21831/jpe.v7i2.26594

doi https://doi.org/10.21831/jpe.v7i2.26594

\section{Introduction}

To foster the prosperity of a nation, education should be the aspect that gains the top priority (Purwanto, 2006; Susanti, 2014). In this regard, education in Indonesia has still been low in terms of quality based on the results of the Programme for International Student Assessment. Since 2015, out of 72 countries, Indonesia has still earned the $62^{\text {nd }}$ Rank and Indonesia has still been left behind Vietnam (OECD, 2016). The Programme for International Student Assess- ment, also known as PISA, itself views three aspects within the 15 years-old teenagers namely Science, Mathematics and Literacy. The results of this assessment program should be an alarming notification for the Indonesian government and the educational stakeholders within the evaluation of the progress of Indonesian education in the future (Tjalla, 2010). Then, the low quality of Indonesian education has been caused by the educator quality (Priscilla, 2019), the student interest, the educational supporting facilities and the curriculum implementation that has not paid 
attention to the local wisdom among the Indonesian people. Not to mention, the problems of human resources quality and quantity has not been solved by the implementation of 2013 Curriculum especially if the implementation of the curriculum does not put high priority on the cognitive, affective and psychomotor aspects in accordance to the demands of the employment in the $21^{\text {st }}$ Century, which has been manifested in the STEM (Science, Technology, Engineering and Mathematic)-based education (Firman, Rustaman, \& Suwarma, 2015).

The mastery on the domain of Science, Technology, Engineering and Mathematic might be pursued through the STEM approach. The results of a study by (Hudha et al., 2019; Rachmawati, Suhery, \& Anom, 2017) show that STEM has been considered capable of generating the students who master numerous competencies. IN the same time, the STEM-based education has been considered capable of activating students' scientific reasoning skills and of encouraging the students to benefit the technology for the sake of preparing their future (English \& King, 2015). Departing from the two statements, it is apparent that the STEM approach strives to combine several domains, namely Mathematics, Engineering, Technology and Science, into one functional domain (Utami, Jatmiko, \& Suherman, 2018). Chittum, Jones, Akalin, and Schram (2017) states that STEM has concepts and activities for motivating the students so that the students might learn more and also brings about positive impacts on the students' perception toward Science.

The learning pattern through the STEM approach has been proven to provide positive impacts in improving the students' achievements both in the academic and the non-academic domains from the interested improvement toward the wider level. It can bee is seen that there is an increase in interest, emphasis and interest in STEM-based schools and the need for understanding student outcomes (LaForce et al., 2016). This situation occurs after the teachers incorporate the STEM into the learning process. After the incorporation, the students' cognitive aspects start to improve; the students start to apply the problem-solving approaches and they are encourageed to pursue innovations (Permanasari, 2016). From his study (Supporting Integrated STEM in the elementary school), it is said that it is needed more support to enact or realize for students to be able to conceptualize the content of STEM in the classroom (Estapa \& Tank, 2017). To develop and change teachers is to participate in STEM activities and engage in social activities that influence changes in student (Aslam, Adefila, \& Bagiya, 2018). These statements imply that the STEM can improve and develop the teachers and, consequently, the STEM might be implemented into the social activities that might influence better changes among the students.

To support the implementation of multiple learning methods, the STEM approach might be considered as part of the implementation due to its integrative nature. The incorporation of the STEM approach into the implementation of these multiple learning methods might cause the teachers to be more creative in delivering the learning materials to the students. STEM education that has been well-integrated has the opportunity to create programs through a social discourse to integrate complementary learning theories as desired (Kelley \& Knowles, 2016). Therefore, the learning media with the local wisdom approach might be developed as a solution for generating well-qualified students who are capable of solving problems, who perform critical and logical thinking, who understand learning materials and who are capable of associating their own cultures in the learning process within the classroom. According to (Gagné, 1985), to stimulate the students to learn the learning media might be turned into the learning components among the students. (McDonald, 2016), the knowledge and understanding of science materials, science pedagogy skills and self-confidence are needed by a teacher in STEM education to create a conducive and ideal learning condition.

In the elementary and high education of many countries, including Indonesia, what becomes the part of the conventional curriculum in Science and Mathematics whereas Technology and Engineering only occupy a very small portion in the curriculum. Mathematics and Science can be the support for STEM education. In relation to the statement, Bybee (2013) categorizes STEM into nine patterns of the standalone subject until it can be combined into a learning integration. Up to date, the government has issued the learning sources for 2013 Curriculum in the form of textbooks that both the teachers and the students. However, the textbooks have not benefitted the STEM approach. From the results of the analysis toward the textbooks for both the students and the teachers, it is found that the Science, Engineering, and Mathematics have been integrated whereas the Technology has been less integrated into the textbooks. Consequently, the approach 
that has been adopted is SEM or the approach has not been fully adopted. For instance, in the learning process of Nature History on the types of organisms and their food, the textbooks tend to display written materials without being accompanied by interesting colours and figures for the students during the implementation of the STEMintegrated learning process.

Media refer to the display tools that have been intended toward presenting the learning materials that the teachers should deliver in the form of photographs and also refer to the graphical tools that have been intended toward capturing, processing and devising information verbally and visually (Arsyad, 2002, p. 3). In addition, media might also be benefitted as the tools for delivering the content of books or materials from the educators to the educated or the students. Teaching materials are a very important tool for teachers because these tools are needed at the teaching and learning process; it is also contained in school subject, helps the teachers teach efficiently and can improve student performance (Olayinka, 2016, pp. 32-39). Then, essentially learning media have benefits in (1) improving the stimulus to the learning participants within the learning process; (2) providing descriptions to the students with regards to the actual condition of an object; (3) providing descriptions from something abstract into something concrete; (4) pursuing equal view toward something under investigation; (5) facilitating teachers in delivering shorter and more efficient presentation; (6) providing recurrent information continuously; and (7) delivering more effective and interesting learning conditions (Sanaky, 2013, p. 7). On the other hand, according to (Dewi \& Harahap, 2016, p. 68) with the existence of teaching materials, a teacher can make students active and able to give them space to develop their abilities based on their characteristics.

All of the problems that have been elaborated previously are also found in the Muhammadiyah Ambarbinangun Elementary School Yogyakarta. Due to these problems, the apparent impact is that the students have a less in-depth understanding of the materials that the teachers have delivered during the teaching-learning process in the classroom. These problems should be solved by the teachers to reactivate the critical and active thinking among elementary school students. Thus, the teachers are demanded to be able to deliver interesting learning innovations especially with regards to the delivery of interactive media in the learning process. In the same time, the media that should be selected are the ones that might stimulate the higher-order thinking skills (HOTS) and that might be related to the students' daily routines. This matter is very important because the students in the Muhammadiyah Ambarbinangun Elementary School Yogyakarta have a low level of activeness and problem-solving skills and such situation has been reflected by the learning manner of the students in the classroom. These students are less independent in solving problems that they have found in the learning process. Not to mention, the thematic learning process that the teachers have implemented are still conventional and teachercentred, which rely on the use of the lecture and the question-and-answer session by the teachers. Such conditions cause the students unable to solve the problems and masterless learning materials within the learning process.

Looking at these problems, an alternative learning source in the form of STEM-integrated encyclopaedia that might facilitate the students in mastering the learning materials is deemed necessary to design. Indeed, the encyclopaedia is part of printed textbooks but encyclopaedia has different characteristics. Through the encyclopaedia, the learning materials might be presented in a more interesting manner complete with the illustrations that the students might understand well (Ubaidillah, 2017). Therefore, within the conduct of the present study, the STEM-integrated encyclopaedia will be developed as the learning source. The development of this encyclopaedia will be different in comparison to the development of any other encyclopaedia because the present encyclopaedia will integrate the STEM education, namely the education that has been based on the four different disciplines (Science, Technology, Engineering and Mathematics) and will also provide examples of technological implementations that might be benefitted in the learning materials of Temperature and Heat among the students' daily activities. The development of such encyclopaedia is deemed effective to solve the students' learning problems because the display and the concepts that will be presented in the encyclopaedia are more interesting. In addition, the encyclopaedia will be equipped by relevant pictures, illustrations and materials so that the students will be more interested to benefit the encyclopaedia as the media for mastering the objectives that have been desired from the learning process. Furthermore, the encyclopaedia is believed to be able to improve the critical thinking skills or the higher 
order thinking skills since the encyclopaedia contains information and a number of other information that contains general and complex knowledge. The accuracy and the update within the encyclopaedia themselves make the encyclopaedia worthy to serve as an alternative learning source (Ubaidillah, 2017).

The encyclopaedia that will be developed within the study is intended for Grade V students because these students are demanded to master and understand the given learning materials more to deepen their knowledge. More specifically, the learning materials of Temperature and Heat will be developed throughout the encyclopaedia since the students have not mastered the learning materials provided in the textbooks well. Through the development of the encyclopaedia, it is expected that the students' thinking skills, namely the one that is based on the STEM approach, will be activated. In brief, the objective of the study is to elaborate the steps within the development of STEM-integrated encyclopaedia and also to identify the fitness and the effectiveness of the STEM-integrated encyclopaedia for the learning materials of Sun, Temperature and Heat.

\section{Method}

The method that had been adopted within the conduct of the study was Research and Development (R\&D) with the ADDIE learning design. The framework of the method within the conduct of the study might be consulted in Figure 1.

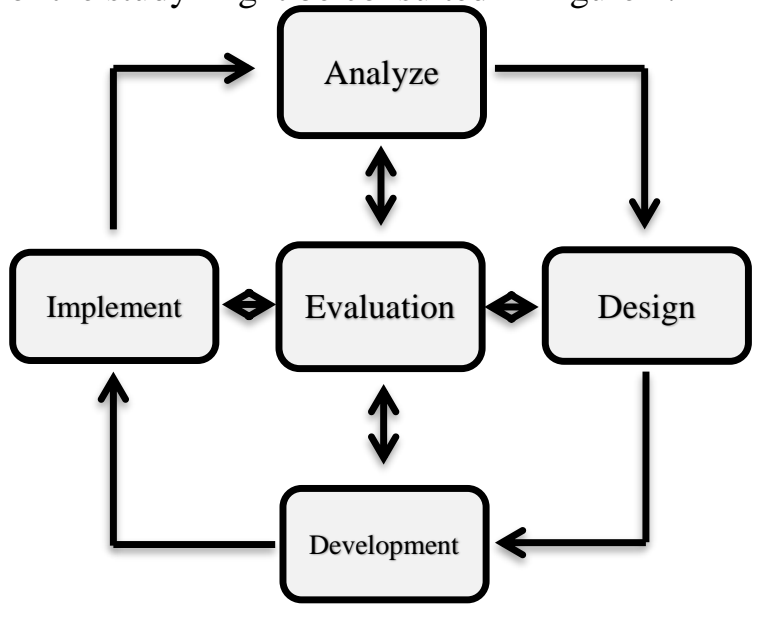

Figure 1. ADDIE Approach

Then, the subjects for the conduct of the study were the Grade VA students, who consisted of 24 people. After the results had been gathered, the results were analysed and were revised in order to yield the final results so that the final results might be fit for implementation in the Elementary School degree. Furthermore, the operational field test/the effectiveness test was performed with the students from Grade VB of Muhammadiyah Elementary School Ambarbinangun Yogyakarta as the subjects.

The data-gathering instruments that had been used within the study were questionnaire, test and instrument while data analysis techniques that had been adopted were quantitative analysis and qualitative analysis. The quantitative data consisted of product assessment sheet that had been assessed by the media expert, the material expert, the learning expert, the teachers and the students, whereas the qualitative data consisted of the review results, the criticisms, the suggestions provided by the expert who validated the materials, the suggestions provided by the expert who validated the media, the suggestions provided by the expert who validated the learning, the teachers and the students. The quantitative data were in the form of assessment score 1 for every "YES" answer and 0 for every "NO" answer; on the other hand, the qualitative data were in the form of range score with the following criteria: 4 = "Very Good," 3 = "Good," $2=$ "Poor," and 1 = "Very Poor" (Arikunto, 2016, p. 146). These scores were attained from the total score of each expert in the expert judgment process. Within the data analysis, the one group pre-test post-test design was adopted $\mathrm{n}$ the conduct of the operational field test to view the comparison between the situations before and after the media use (Sugiyono, 2015); the $\mathrm{O}_{1}$ or the pre-test results were compared to the $\mathrm{O}_{2}$ or the post-test results. In addition to the comparison, the influence of both the pre-test and the post-test toward the STEM-integrated encyclopaedia was also measured within the analysis of the overall results of one group pre-test post-test design.

\section{Results and Discussions}

From the results of the study that has been conducted, a STEM-integrated encyclopaedia learning media is generated for the enrichment of the learning materials on Temperature and Heat for the Grade V students. The process within the product development consists of several stages, regarding the ADDIE model. These stages will be elaborated in the following sub-sections.

Analysis

The first stage within the development of the STEM-integrated encyclopaedia consists of three parts, namely data analysis on the problems and the needs toward the media, curriculum analysis and analysis of students' characteristics. 
Each part will be elaborated further in the following sub-sections.

\section{Data Analysis on the Problems and the Needs toward the Media}

In the stage of field problems analysis, observation and dialogue were conducted in the school to attain the data in the form of field notes and information with regards to the problems of the necessary media, the curriculum application and the characteristics of the students in the school. The observation and the dialogue, specifically, the open dialogue, were held with both the teachers and the students in the Muhammadiyah Elementary School Ambarbinangun Yogyakarta to gather the necessary data. In this stage, several problems that had been found in the Muhammadiyah Elementary School Ambarbinangun Yogyakarta, specifically the ones that had been related to the Grade V students, were identified. The results of the problem identification showed that the students had not clearly understood the learning materials of Temperature and Heat. The reason seemed to be that the teachers had not provided any visualization during the learning materials delivery within the learning process. Also, the enrichment textbooks for the students of Muhammadiyah Elementary School Ambarbinangun Yogyakarta had not been available yet; consequently, the students only relied on the textbooks that the government had provided. Then, the results of the problem identification also showed that the teachers had not developed any supporting textbook for the learning activities. In the same time, the teachers had been unable to optimize the existing learning media. For example, there were still several obstacles that had been found on the use of PowerPoint files or learning videos because the supporting tools for these media had been limited. As a result, the teachers were unable to operate these tools.

In other words, the results of the observation and the interview in the Muhammadiyah Elementary School Ambarbinangun Yogyakarta implied that any STEM-integrated learning media had not been developed yet. From the results of the observation itself toward the Grade V students, it was found that the Grade V students had been unable to solve their problems independently in the classroom. The teachers still dominated the problem-solving activities within the classroom since the students were less active and less critical in responding to what the teachers had delivered. The reason was that the learning process had still been teacher-centred and, consequently, the students were busy with themselves and did not pay attention to the teachers; not to mention, the method that the teachers had adopted in the classroom was conventional and the teachers had also lacked learning media. In sum, all of these situations led to the students' low understanding of the learning process that the teachers had implemented.

Another problem that had been found among the students was ta the students' reading interest had been very low due to the less maximum use on the textbooks that had been distributed. The students were fond of playing pictorial card games, which had been useless. The lack of learning media or learning sources that drew the interest or the curiosity of the students to learn, become one of the factors behind the low reading interest among the students. Therefore, a STEM-integrated encyclopedia for the learning materials of Temperature and Heat would be developed based on the problems among the Grade V students of Muhammadiyah Elementary School Ambarbinangun Yogyakarta. The presence of the STEM-integrated encyclopedia was expected to serve as the supporting textbooks for the learning materials of Temperature and Heat so that the students might be facilitated in learning those materials.

Based on the results of the needs analysis toward both the teachers and the students, the solution that might be devised was developing the STEM-integrated encyclopaedia that would be fit into the characteristics and the development of the students and that would also facilitate the teachers in their teaching activities. Such encyclopaedia was expected to facilitate the students as well in solving the problems and pursuing critical thinking within the learning process.

\section{Curriculum Analysis}

After analysing the problems and the needs, the curriculum and the syllabus that had been designed were also analysed. The curriculum that had been implemented in the Muhammadiyah Elementary School Ambarbinangun Yogyakarta was the 2013 Curriculum. After the curriculum and the syllabus had been analysis, the media that fitted into the results of the needs analysis were developed to stimulate the students' critical thinking skills and to improve their learning achievements. Then, the results of the needs analysis and the curriculum analysis showed that the STEM-integrated encyclopaedia 
had been fit for the learning materials of Sun, Temperature and Heat.

\section{Analysis of Students' Characteristics}

The students' characteristics were analysed to describe the problems that the students experienced in their learning process. Based on the results of the characteristics that the Grade V students of Muhammadiyah Elementary School Ambarbinangun Yogyakarta had, it was found that the students had been less active, the students had been unable to solve the problems in their classroom independently and the students had lower understanding level toward the learning materials that had been delivered (Temperature and Heat). In the same time, the Grade V students displayed less interest in reading activities. Such a low level of reading interest led to the conclusion that the STEM-integrated encyclopaedia should be developed as the support for the learning process.

On the other hand, the method that the teachers had adopted in the classroom was also one of the triggers behind less enthusiasm among the students in attending to the learning process. Based on the results of the observation in the classroom, it was apparent that the students had been busy with their own business or had been busy picking up their classmates and they had not paid attention to their teachers properly whereas their teachers had been delivering the learning materials. The students seemed to be bored during the learning process and it was the reason why the students committed useless things during the learning process. Through both of the observation activities and the interview activities, it was found that a STEM-integrated learning media for the learning materials of Temperature and Heat should be developed as alternative media or supporting media for the teachinglearning process.

Design

After performing the needs analysis through the observation, the learning product in the form of teaching materials and design is compiled. Specifically, the learning product is STEM-integrated encyclopaedia. The stages in designing the STEM-integrated encyclopaedia will be elaborated in the following sub-sections.

\section{Designing the Framework of STEM-Integrated Encyclopaedia}

The design for the framework of STEMintegrated encyclopaedia was developed in the following order: (1) Part 1, which consisted of: cover page, main page, developer page, foreword, preface, table of content, manual, Core Competencies, Basic Competencies, Indicators and Learning Objectives; (2) Part II, which consisted of separators, prologues, introductory pictures, three maps of material concept, three materials (Temperature, Heat and Characteristics and Changes of Matters), quizzes entitled "Let's Practice, Let's Try" and "Did You Know?" page; and (3) Part III, which consisted of index lists, list of pictures, references, biography and back-cover page.

\section{Presenting Pictorial and Material Illustrations}

The material presented in the encyclopaedia was based on the elaboration of basic competences and indicators. The order within the material presented in the STEM-integrated encyclopaedia was as follows. The first learning materials were under the title "Temperature"; these learning materials were equipped with the concept map and contained the definition of Temperature, the manner of measuring Temperature by using hand gestures, the thermometer, the manner of reading the thermometer and the influence that might have been caused by the changes on the Temperature. Then, the second learning materials were under the title "Heat"; these learning materials were equipped with the concept map that discussed the definition of Heat, the transfer of Heat, the comparison on the surface width, the use of Heat, the heat conductors and the heat isolators and also the benefits of the heat conductors and the heat isolators. Next, the third learning materials were under the title "Characteristics and Changes of Matters"; these learning materials were equipped with the concept map that discussed the characteristics of matters (liquid, solid and vapour) and the changes of matter (melt, freeze, evaporate, condense, sublime and crystallize). In addition, the third learning materials were also equipped with the quizzes, the section under the title "Did You Know?", the simple experiment and the evaluative test items. Each of these learning materials was equipped with the supporting pictures and illustrations so that these materials might be visualized and thus the students might be facilitated in understanding the learning materials.

\section{Planning the Media Design}

The first step in designing the STEMintegrated media was defining the title of the media. The title was based on the results of the 
needs analysis in the school. Then, the design in the encyclopaedia was similar to any typical media; however, the encyclopaedia that had been developed in the study had a peculiar difference namely that the STEM learning would be integrated into the encyclopaedia. Then, the STEMintegrated encyclopaedia consisted of evaluative test items, quizzes, simple experiments and sections under the title "Did You Know?" Then, the STEM-integrated encyclopaedia was designed by developing a simple storyboard with reference to several aspects in terms of the media display, colours combination in use, size, layout, font type and illustrations in each material under the systematic presentation.

\section{Designing the Research Instrument}

The research instrument was the media validator sheet, the material validator sheet, the learning process validator sheet, the teacher questionnaire and the student questionnaire. For the expert validator sheet and the teacher response questionnaire, the Likert scale was adopted to test the fitness of the STEM-integrated encyclopaedia. On the other hand, for the student questionnaire different approach was adopted: every "YES" answer was scored 1 while every "NO" answer was scored 0 . The components of assessment in the instrument and the questionnaire were different by the needs of the study and concerning the theory that had been adopted and that had been developed. The instrument and the questionnaire had been consulted to the research instrument experts first and the results of their judgment showed that both the instrument and the questionnaire had been fit for the conduct of the study.

\section{Development}

After the needs analysis has been conducted through observation, the draft of the STEMintegrated encyclopaedia as the product is developed by relying on the learning materials under the title "Temperature" and "Heat." The design that has been developed is interesting and is in accordance with the characters of the students.

\section{Pre-Drafting Activities of STEM-Integrated Encyclopaedia}

The delivery of materials in the STEMintegrated encyclopaedia was performed by using multiple resources and references as well as pictures that had been related to the materials of Temperature and Heat. The sources that had been used as the materials for the STEM-integrated encyclopaedia were, namely, the thematic textbooks of 2013 Curriculum for Grade V students, the thematic textbooks of 2013 Curriculum for teachers, the BSE books, the Educational Unit Level Curriculum textbooks for Grade V students, the modules and the other manual books. The pictures in these sources were useful for describing the materials completely and also useful for visualizing the materials that had been delivered.

\section{Drafting Activities of STEM-Integrated Encyclopaedia}

The stages of drafting the activities of STEM-integrated encyclopaedia consisted as follows: (1) the STEM-integrated encyclopaedia based on the materials of "Temperature" and "Heat" in 2013 Curriculum; and (2) the STEMintegrated encyclopaedia was designed based on the Material Delivery and the Graphical Delivery. The drafting activities for the graphics were adjusted to the framework of the graphic model in the STEM-integrated encyclopaedia. Then, the STEM-integrated encyclopaedia was adjusted based on the parts that facilitated the students in understanding the learning materials. The sections within the STEM-integrated encyclopaedia might be elaborated as follows.

\section{Cover Page}

The encyclopaedia was entitled "The STEM-Integrated Encyclopaedia for the Materials of Temperature and Heat in Grade V of Elementary Schools/Madrasah Ibtidaiyah." The names of the authors were written on the cover page in order to provide information on the authors. Then, the logo and the label "STEMIntegrated" were inserted to mark that the encyclopaedia that had been developed served as the reading materials and the enrichment materials for "Temperature" and "Heat" with the integration of STEM. Then, the cover page was decorated using the illustrations that had been related to the materials in the STEM-integrated encyclopaedia namely: thermometer, ice cream and campfire. Furthermore, the colours that had been selected for the cover page were the combination of yellow, white and blue. Such colour combination was selected to draw the interest of the students. At the bottom of the cover page, the logo of Ahmad Dahlan University was inserted.

\section{Author Page}

The author page consisted of the title, the name of the author, the name of the validators, 
the layout design and the information on the design of the STEM-integrated encyclopaedia.

\section{Foreword}

The foreword was given by the authors and contained introductory notes, acknowledgements, words of grace to God the Almighty the information and the expectations from the authors to the readers.

\section{Preface}

This page contained the introduction of both the book and the authors. In this page, the authors shared their minds with regards to the process of the book authorship and development.

\section{Table of Contents}

The table of the content contained the list of the materials that had been inserted into the STEM-integrated encyclopaedia.

\section{User Manual}

The user manual of the STEM-integrated encyclopaedia aimed at facilitating the readers in looking for the relevant materials. The relevant materials might be searched by directly tracing the index or the title in the encyclopaedia.

\section{Core Competencies-Basic Competencies- Indicators and Learning Objectives}

The core competences-basic competences - indicators and also the learning objectives in the STEM-integrated encyclopaedia were useful for identifying the achievement of the readers in understanding the learning materials.

\section{Inter-Learning Materials Separators}

The inter-learning materials separators servedas the separator between the previous materials and the subsequent materials within the STEM-integrated encyclopaedia.

\section{Concept Map}

The concept map served to provide the materials that would be discussed in the STEMintegrated encyclopaedia.

Quiz

The quiz in the STEM-integrated encyclopaedia was a simple one and only demanded short answers. However, the objective of the quiz was to elicit the students' knowledge and critical thinking skills.

\section{“Do You Know?" Section}

"Do You Know" section contained the information that might expand the students' or the readers' knowledge.

\section{Simple Experiment / "Let's Try" Section}

The simple experiments in the STEMintegrated encyclopaedia aimed at improving the students' creativity in devising something by means of certain techniques or in identifying conclusions through the conduct of certain experiments

\section{"Let's Practice" Section}

The "Let's Practice" section contained exercise test items for each material in each chapter. This section aimed at evaluating the achievement of the students in each chapter.

Index

The index contained the list of significant words or terms with regards to the materials that had been discussed. The index was inserted at the end of the encyclopaedia and was in alphabetical order so that the readers would be easily facilitated in looking for the pages of certain words or terms.

\section{References}

The references contained the material sources or the material references within the design of the STEM-integrated encyclopaedia.

\section{Authors' Biography}

The authors' biography contained the information on the background, the experience, the achievement and the expectation of the authors with regards to the STEM-integrated encyclopaedia.

\section{Back Cover Page}

The back cover page contained the general description of the materials in the STEMintegrated encyclopaedia.

\section{Implementation}

The final product that has been perfected through revision and validation is implemented in the elementary school degree. The implementation has taken place in the Muhammadiyah Elementary School Ambarbinangun Yogyakarta. The product is implemented twice: the first implementation has taken place in the field test with the students as the subject, while the second implementation has taken place in the operational 
field test. The sequence of the implementation might be described in the following sub-sections.

Data from the Experiment of the STEMIntegrated Encyclopaedia

After the STEM-integrated encyclopaedia had been declared fit for implementation by the experts, the STEM-integrated encyclopaedia was sent to the field implementation. The sequence of the field implementation was as follows: (1) the first sequence was the field implementation with 24 students of Grade VA in Muhammadiyah Elementary School Ambarbinangun Yogyakarta as the subjects; and (2) the second sequence was the operational field test/the effectiveness test wit 30 students of Grade VB in Muhammadiyah Elementary School Ambarbinangun Yogyakarta as the subjects.

\section{Data from the Results of Teachers' Assessment Test}

The teachers' assessment test was performed in order to test the fitness of the STEMintegrated encyclopaedia. The data that had been attained from the results of this test were analysed through the following sequence: (1) tabulating the overall data; (2) calculating the overall data from all assessment aspects; and (3) converting the overall scores by using the First Equation Formula. In the first equation formula, $\mathrm{N}$ was the score, $\sum \mathrm{x}$ was the score that had been attained and $\sum \max$ was the maximum score.

$X=\frac{\sum x}{\sum \max } \times 100$

When the score from each expert had been attained, the mean score should be calculated by using the Second Equation Formula. In the Second Equation Formula, $\mathrm{X}$ was the mean score, $\sum \mathrm{x}$ was the total score, and $\mathrm{N}$ was the total rater.

$X=\frac{\sum x}{N}$

After the overall score had been attained, the overall score was assigned into the percentage of fitness that consisted of four categories namely "Very Good," "Good," "Poor," and "Very Poor."

Evaluation

Assessment is the last part of the ADDIE model. Evaluation is conducted to ensure that the data that have been attained to the product development is already fit for implementation in the wider scale (fit, valid and practical).

After the experiment has been conducted, the data that have been attained from the experts' questionnaire (the media expert, the material expert and the learning expert) are analysed. In the same time, the teachers and the students are also invited to complete the teacher questionnaire and the student questionnaire with regards to the implementation of the STEM-integrated encyclopaedia. In addition to the questionnaire completion, the students are provided with the pretest and the post-test administration to test the media effectiveness.

On the other hand, the data that are in the form of criticisms and suggestions from the experts about the media, the learning materials and the learning process, as well as the data from both the teachers and the students who have assessed the STEM-integrated encyclopaedia, are analysed qualitatively. The results of the qualitative data analysis are presented in the following sub-sections.

\section{Data Analysis from Media Expert}

The media expert who had been invited as the product validator was Mrs Probosiwi. In addition to assessing the assessment questionnaire by using the scoring system, the expert provided criticisms, suggestions and feedback for the development of the STEM-integrated encyclopaedia. The assessment was conducted by using the teaching materials in the form of description toward the relevance of the media that have been developed. Then, the criticisms, the suggestions and the responses by the media expert were as follows: (1) the type of paper that had been used in the media content was still too thick and consequently, the students had difficulties in opening the encyclopaedia because the papers were stiff; and (2) the binding of the encyclopaedia was not tidy and therefore the binding should be improved.

\section{Data Analysis from Material Expert}

The criticisms, the suggestions and the responses from the material expert were part of the assessment that had been processed into the qualitative data in the form of description or narrative. The description or the narrative was useful for improving the quality of the STEMintegrated encyclopaedia that had been developed. Then, the criticisms, the suggestions and the responses that the material expert had provided were namely: (1) adding a prologue into the materials before the discussion of the "Heat" chapter; (2) adding other examples of the conductor; and (3) adding other examples of the isolator. 


\section{Data Analysis from Learning Expert}

The learning expert had not only provided the assessment in the form of the score but also in the form of criticisms, the suggestions and the responses which were constructive for the improvement of the STEM-integrated encyclopaedia that had been developed. The objective of providing the criticisms, the suggestions and the responses was to correct the media that had been developed. Then, the criticisms, the suggestions and the responses that the learning expert has provided were namely: (1) the indicators should be designed in accordance to the order of the materials in the STEM-integrated encyclopaedia; and (2) the learning objectives should be inserted into the STEM-integrated encyclopaedia.

\section{Data Analysis from Teachers and Students}

Within the conduct of the study, in addition to the expert validation that provided the assessment toward the STEM-integrated encyclopaedia that had been developed, both the teachers and the students were invited to provide their assessment as well. During the test with the Grade V students and the product test with the teachers, several comments on the STEM-integrated encyclopaedia had been gathered. In general, the comments implied that the media had been interesting and by the quality that both the teachers and the Grade V students in the Muhammadiyah Elementary School Ambarbinangun had expected. The media that had been developed were interesting, easy to understand for both the teachers and the students during the learning process and also encouraging the students to learn and increasing the students' curiosity.

About the qualitative data analysis, the quantitative data analysis referred to the activities of processing the data that had been attained from the expert validation assessment, the teacher's assessment and the student assessment in the form of scores. Besides, the qualitative data analysis might also refer to the activities of processing the data that had been attained from the effectiveness test toward the teaching materials that had been developed from the students' pre-test and post-test results. The results of the quantitative data analysis were presented under the following principle: if the assessment had been conducted then the scores that had been attained should be calculated by using formula (Arikunto, 2016, p. 236). Then, the STEMintegrated encyclopaedia was considered fit if the category of the scores that had been attained would have fallen into "Very Good." Therefore, the STEM-integrated encyclopaedia was possibly considered to be unfit for implementation if the category of the scores that had been attained fell into "Poor." On the other hand, the STEMintegrated encyclopaedia might be considered fit if the category of the scores that had been attained exceeded "Moderate." These statements thus might be used for identfying the fitness of the STEM-integrated encyclopaedia as the enrichment for the learning materials of Temperature and Heat among the Grade V students of Elementary School degree.

\section{Product Fitness Analysis}

The results of the product fitness analysis for the STEM-integrated encyclopaedia will be elaborated in the following sub-sections.

\section{Data Analysis from the Product Validation Test}

Table 1. Data from the Results of Product Validation Test

\begin{tabular}{clr}
\hline No. & Expert Validation & Percentage \\
\hline 1. & Media Validator & 93.75 \\
2. & Material Validator & 81.81 \\
3. & Learning Validator & 73.80 \\
& Total Score & 249.36 \\
& Mean Score & 83.12 \\
\hline
\end{tabular}

Based on the results in Table 1, it is apparent that the overall mean score of the assessment that each expert has provided is $83.12 \%$. The implication is that the STEM-integrated encyclopaedia as the enrichment for the materials of Temperature and Heat might be categorized into "Very Fit." Therefore, based on the overall score of the validator, the STEM-integrated encyclopaedia might be very fit for implementation.

\section{Data Analysis from the Student Assessment}

Table 2. Data from the Results of Student Assessment

\begin{tabular}{llr}
\hline No. & \multicolumn{1}{c}{ Student Assessment } & Percentage \\
\hline 1. & Field Test (Grade VA & 91.91 \\
& $\begin{array}{l}\text { Students) } \\
\text { 2. }\end{array}$ & 89.85 \\
& $\begin{array}{l}\text { Operational Experiment } \\
\text { (Grade VB Students) }\end{array}$ & 181.76 \\
& Total Score & 90.88 \\
\hline
\end{tabular}

Based on the results in Table 2, 90.88\% of students consider that the STEM-integrated encyclopaedia as the enrichment for the materials of Temperature and Heat belongs to the "Very Fit" category. Therefore, it might be concluded that based on the mean score form the field test and 
the operational field test, the STEM-integrated encyclopaedia has been very fit for implementation in the learning process.

\section{Data Analysis from the Teacher Assessment}

Table 3. Data from the Results of Teacher Assessment

\begin{tabular}{clr}
\hline No. & Teacher assessment & Percentage \\
\hline 1. & Grade VA Teacher & 100.00 \\
2. & Grade VB Teacher & 88.04 \\
& Total Score & 188.04 \\
& Mean Score & 94.02 \\
\hline
\end{tabular}

Based on the results in Table 3, the mean score that has been attained from the two teachers of Grade V in Muhammadiyah Elementary School Ambarbinangun Yogyakarta is $94.02 \%$. In other words, the two teachers consider that the STEM-integrated encyclopaedia as the enrichment for the materials of Temperature and Heat belongs to the "Very Fit" category. Therefore, it might be concluded once again that the STEMintegrated encyclopaedia has been very fit for implementation in the learning process.

The overall score of product fitness that the media expert, the material expert and the learning expert, the teachers and the students have provided are accumulated to gain the mean score of the product fitness. The results of the score accumulation for the product fitness might be consulted in Figure 2.

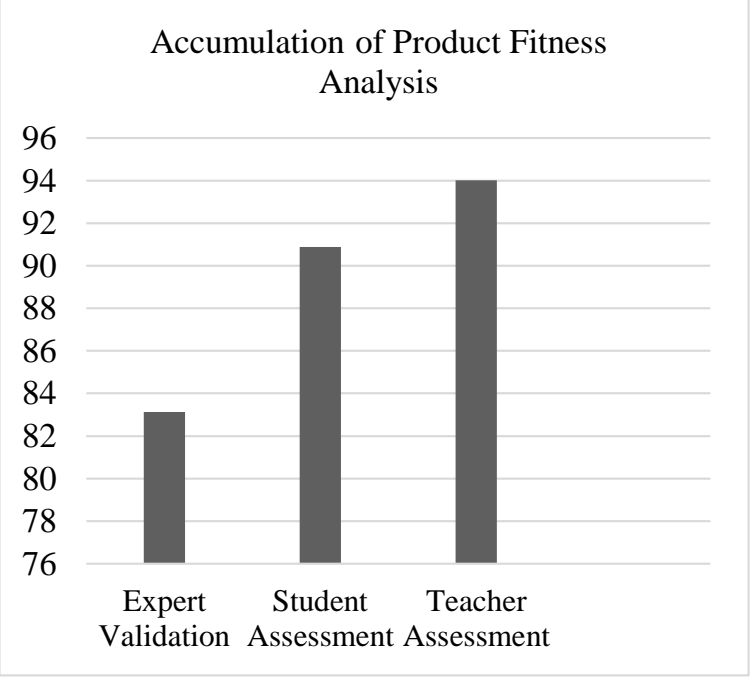

Figure 2. Data from the Results of Score Accumulation in the Product Fitness Assessment

\section{Product Effectiveness Analysis}

The product fitness analysis is performed to identify the level of the effectiveness of the product that has been developed, namely the STEM-integrated encyclopaedia, with reference to the One Group Pre-Test Post-Test design. The model has been implemented in the operational field stage with 29 Grade VB students of Muhammadiyah Elementary School Ambarbinangun Yogyakarta as the subjects. The analysis on the One Group Pre-Test Post-Test Design is conducted using comparison as having been suggested by (Sugiyono, 2015). From the third equation, it is identified that $\mathrm{O}_{1}$ refers to the Pre-Test score or the score before the media implementation, $\mathrm{X}$ refers to the implementation of the STEMintegrated encyclopaedia and $\mathrm{O}_{2}$ refers to the Post-Test score or the score after the media implementation.

\begin{tabular}{|lll|}
\hline $\mathrm{O}_{1}$ & $\mathrm{X}$ & $\mathrm{O}_{2}$ \\
\hline
\end{tabular}

For the data analysis, the concept of comparison between $\mathrm{O}_{1}$ or the Pre-Test score and $\mathrm{O}_{2}$ or the Post-Test score is adopted. In addition to viewing the comparison, the influence of both the Pre-Test and the Post-Test toward the STEMintegrated encyclopaedia is measured. The formula that has been used for measuring the influence is as follows (Sugiyono, 2015).

The Influence of Media $=\mathrm{O}_{2}-\mathrm{O}_{1}$

Based on the analysis with the above calculation formula, the effectiveness of the media that have been developed in the study might be measured.

\section{Normality Test}

Normality test refers to the fact that the data that have been tested might be used for identifying whether the content that will be analysed are normally distributed or not. The formula for the conduct of the normality test is KolmogorovSmirnov. The decision-making basis for the formula is that the data are considered to be normally distributed if the probability or the pvalue is lower than $0.05(p<0.05)$. Then, the normality test is conducted in the operational field test data. Based on the analysis using the Kolmogorov-Smirnov formula, the effectiveness of the media that have been developed might be identified. The results of the normality test might be consulted in Table 4.

Table 4. Results of Normality Test

\begin{tabular}{lccccc}
\hline \multicolumn{2}{c}{ Variable } & $\mathrm{Z}$ & $P$ & Sig. & Status \\
\hline $\begin{array}{l}\text { Data } \\
\text { of Test }\end{array}$ & $\begin{array}{l}\text { Pre- } \\
\text { Test }\end{array}$ & 0.125 & 0.200 & 0.05 & Normal \\
Results & $\begin{array}{l}\text { Post- } \\
\text { Test }\end{array}$ & 0.133 & 0.200 & 0.05 & Normal \\
\hline
\end{tabular}


From the results in Table 5, the p-value is equal to 0.200 or higher than 0.050 . Therefore, it is clear that the Pre-Test data and the Post-Test data have been in a normal distribution. Thus, the data might be analysed further into the hypothesis test.

\section{Hypothesis Test (Paired Sample t-Test)}

Hypothesis test refers to the further action of analysing the data that have been normally distributed in the normal distribution test. In the context of the present study, the hypothesis test is conducted by using the Paired Sample t-Test with the rate of the significance of $5.00 \%$. The objective of conducting the Paired Sample t-Test is identified the differences between two data clusters, namely the Pre-Test data and the PostTest data, on the same samples. Then, the samples that have been taken are the Grade VB students from the Muhammadiyah Elementary School Ambarbinangun Yogyakarta. The results of the hypothesis test might be consulted in Table 5.

Table 6. Results of Hypothesis Test (Paired Sample t-Test)

\begin{tabular}{lccccc}
\hline $\begin{array}{l}\text { Pre-Test dan } \\
\text { Post-Test }\end{array}$ & Df & $\begin{array}{c}\text { T- } \\
\text { table }\end{array}$ & $\begin{array}{c}\text { T- } \\
\text { count }\end{array}$ & p & $\begin{array}{c}\text { Sig. } \\
5 \%\end{array}$ \\
\hline Media & 28 & 2.048 & 10.325 & 0.000 & 0.05 \\
Effectiveness & & & & & \\
\hline
\end{tabular}

The results of the hypothesis test (t-test) show that t-count is higher than t-table (10.325 > 2.048). The implication is that $\mathrm{H}_{0}$ is rejected and $\mathrm{H}_{1}$ is accepted. The significance value (p-value) is 0.000 , which is lower than the $\alpha$ namely 0.050 $(0.000<0.050)$. Therefore, it might be stated that $\mathrm{H}_{1}: \mu_{1} \neq \mu_{2}$. Therefore, it might be implied that based on the Pre-Test data and the Post-Test data the STEM-integrated encyclopaedia has been effective as the enrichment for the materials of Temperature and Heat in the learning process for the Grade V students.

\section{Conclusions}

The development of the STEM-integrated encyclopaedia as the enrichment for the materials of Sun, Temperature and Heat is conducted through 5 stages namely Analysis, Design, Development, Implementation and Evaluation. In the stage of the validation test, the overall mean score that has been attained from the three experts is 83.12. Then, the mean score that has been attained from the field test with the students is 90.88 . Next, the mean score that has been attained from the operational field test with the teachers is
90.88. Therefore, it might be stated that the STEM-integrated encyclopaedia belongs to the "Very Fit" category and thus the encyclopaedia that has been developed is very fit for implementation in the learning process. Then, in the effectiveness test through One Group Pre-Test Post-Test Design, it is found that the data have been normally distributed. In the same time, the results of the hypothesis test show that the t-count is higher than the t-table $(10.325>2.048)$ with the significance value ( $\mathrm{p}$-value) that smaller than the $\alpha$ namely $0.050(0.000<0.050)$. In overall, the calculation results show a significant difference between the pre-test and the post-test. Therefore, it might be safely concluded that based on the results of the validation test, the field test and the operational field test the STEMintegrated encyclopaedia as the enrichment for the materials of Sun, Temperature and Heat is effective for implementation in the learning process.

\section{References}

Arikunto, S. (2016). Dasar-dasar evaluasi pendidikan (5th ed.). Jakarta: Bumi Aksara.

Arsyad, A. (2002). Media pembelajaran. Jakarta: RajaGrafindo Persada. https://doi.org/2002

Aslam, F., Adefila, A., \& Bagiya, Y. (2018). STEM outreach activities: an approach to teachers' professional development. Journal of Education for Teaching, 44(1), 58-70.

https://doi.org/10.1080/02607476.2018.14 22618

Bybee, R. W. (2013). The case for STEM education: Challenges and opportunities. NSTA press.

Chittum, J. R., Jones, B. D., Akalin, S., \& Schram, Á. B. (2017). The effects of an afterschool STEM program on students' motivation and engagement. International Journal of STEM Education, 4(1), 11. https://doi.org/10.1186/s40594-017-00654

Dewi, I., \& Harahap, M. S. (2016). The development of geometri teaching materials based on constructivism to improve the students' mathematic reasoning ability through cooperative learing jigsaw at the class VIII of SMP Negeri 3 Padangsidimpuan. Journal of Education and Practice, 7(29), 68-82. 
Jurnal Prima Edukasia, 7 (2), 2019 - 126

Vera Yuli Erviana, Anjar Purba Asmara

Retrieved

from

https://iiste.org/Journals/index.php/JEP/ar ticle/view/33597

English, L. D., \& King, D. T. (2015). STEM learning through engineering design: fourth-grade students' investigations in aerospace. International Journal of STEM Education, $2(1), \quad 14$. https://doi.org/10.1186/s40594-015-00277

Estapa, A. T., \& Tank, K. M. (2017). Supporting integrated STEM in the elementary classroom: a professional development approach centered on an engineering design challenge. International Journal of STEM Education, 4(1), 6. https://doi.org/10.1186/s40594-017-00583

Firman, H., Rustaman, N. Y., \& Suwarma, I. R. (2015). Development technology and engineering literacy through STEM-based education. In 2015 International Conference on Innovation in Engineering and Vocational Education. Atlantis Press.

Gagné, R. M. (1985). The conditions of learning and theory of instruction. Holt, Rinehart and Winston.

Hudha, M. N., Triwahyuningtyas, D., Rafikayati, A., Fajaruddin, S., Maryani, I., Widiaty, I., ... Permanasari, A. (2019). How is STEM learning for children with special needs in Indonesia? Journal of Physics: Conference Series, $\quad 1402, \quad 44104$. https://doi.org/10.1088/17426596/1402/4/044104

Kelley, T. R., \& Knowles, J. G. (2016). A conceptual framework for integrated STEM education. International Journal of STEM Education, 3(1), 11. https://doi.org/10.1186/s40594-016-0046$\mathrm{z}$

LaForce, M., Noble, E., King, H., Century, J., Blackwell, C., Holt, S., ... Loo, S. (2016). The eight essential elements of inclusive STEM high schools. International Journal of STEM Education, 3(1), 21. https://doi.org/10.1186/s40594-016-0054Z

McDonald, C. (2016). STEM education: A review of the contribution of the disciplines of science, technology, engineering and mathematics. Science Education International, 27(4), 530-569.
Retrieved from http://www.icaseonline.net/sei/december2 016/p4.pdf

OECD. (2016). PISA 2015 results, excellence and equity in education. Organisation for Economic Co-operation and Development. https://doi.org/10.1787/9789264266490-

en

Olayinka, A.-R. B. (2016). Effects of instructional materials on secondary schools students' academic achievement in social studies in Ekiti State, Nigeria. World Journal of Education, 6(1). https://doi.org/10.5430/wje.v6n1p32

Permanasari, A. (2016). STEM education: Inovasi dalam pembelajaran sains. In Prosiding Seminar Nasional Pendidikan Sains (pp. 2016-2023). Bandung: Universitas Pendidikan Ganesha.

Priscilla, D. (2019). Permasalahan Pendidikan di Indonesia. Jakarta.

Purwanto, N. A. (2006). Kontribusi pendidikan bagi pembangunan ekonomi negara. Jurnal Manajemen Pendidikan: Jurnal Ilmiah Adminstrasi, Manajemen Dan Kepemimpinan Pendidikan, 2(2). Retrieved from https://journal.uny.ac.id/index.php/jmp/art icle/view/4051

Rachmawati, D., Suhery, T., \& Anom, K. (2017). Pengembangan modul kimia dasar berbasis STEM problem based learning pada materi laju reaksi untuk mahasiswa program studi pendidikan kimia. In Seminar Nasional Pendidikan IPA (Vol. 1, pp. 239-248). Palembang: Universitas Sriwijaya. Retrieved from http://www.conference.unsri.ac.id/index.p $\mathrm{hp} / \mathrm{semnasipa/article/view/692}$

Sanaky, H. A. H. (2013). Media pembelajaran interaktif-inovatif. Yogyakarta: Kaukaba Dipantara.

Sugiyono, S. (2015). Metode penelitian dan pengembangan. Bandung: Alfabeta.

Susanti, M. H. (2014). Model pendidikan kewirausahaan di perguruan tinggi dalam menumbuhkan entrepreneur muda kreatif dan inovatif di Kota Semarang. In Forum Ilmu Sosial (Vol. 41). https://doi.org/10.15294/fis.v41i1.5377

Tjalla, A. (2010). Potret mutu pendidikan indonesia ditinjau dari hasil-hasil studi 
Jurnal Prima Edukasia, 7 (2), 2019 - 127

Vera Yuli Erviana, Anjar Purba Asmara

internasional. In Teтu Ilmiah Nasional Guru II: Membangun Profesionalitas Insan Pendidikan Yang Berkarakter dan Berbasis Budaya. Tangerang Selatan. Retrieved from http://repository.ut.ac.id/2609/

Ubaidillah, M. (2017). Pembelajaran berbasis proyek untuk mengembangkan ensiklopedia berbasis bioedupreneurship. JURNAL PENDIDIKAN SAINS (JPS),
$5(1)$, $32-40$. https://doi.org/10.26714/jps.5.1.2017.3240

Utami, T. N., Jatmiko, A., \& Suherman, S. (2018). Pengembangan modul matematika dengan pendekatan science, technology, engineering, and mathematics (STEM) pada materi segiempat. Desimal: Jurnal Matematika, $\quad$ I(2), 165. https://doi.org/10.24042/djm.v1i2.2388 